FOLIA SCANDINAVICA VOL. 25 POZNAŃ 2018 DOI: $10.2478 /$ fsp-2018-0016 sciendo

PRESSto.

\title{
EXTRAORDINARY PROTAGONISTS,
} AVERAGE ISSUES

\author{
SOCIAL PROBLEMS IN MODERN FINNISH \\ THRILLERS BY ILKKA REMES \\ AND TAAVI SOININVAARA
}

\author{
MARTYNA KOKOTKIEWICZ
}

Adam Mickiewicz University in Poznań

\begin{abstract}
Thriller is considered to be a subgenre of criminal fiction, in which the most significant role is played by fast-paced action, suspense, spectacular events. In case of so called international and political thrillers it should also be mentioned that their authors construct their plots around the problems such as global conflicts, international conspiracy, terrorism, the development of nuclear weapon. However, problems commonly mentioned by many authors of other subgenres of criminal fiction, are also present in the novels classified as thrillers. The collapse of wellbeing society, unstable interpersonal relationships, mental problems of an individual, childhood traumas are therefore often mentioned by the writers, although they do not usually constitute main subjects of the novels. The article concentrates on some examples from international and political thrillers, in which such issues seem to be equally important, written by the most popular Finnish authors of this particular genre, namely Ilkka Remes and Taavi Soininvaara.
\end{abstract}

\section{THRILLER WRITERS IN FINLAND - INTRODUCTION}

Thriller with its different subgenres has recently developed significantly in Finland, as well as in Northern Europe in general. The genre cannot be considered a new literary phenomenon as it has, according to some approaches, its roots in the Gothic novel (Scaggs 2005:106, 1079). However, its popularity has been growing considerably in recent years. It may be assumed that it is nowadays the fastest-growing branch of criminal fiction. The most important subgenres to be mentioned are political, psychological, 
surveillance thrillers and, most recently, so called eco-thrillers (Arvas \& Ruohonen 2016:135, 152). According to some scholars in their works concentrating on the categorization of different subgenres and the development of criminal fiction, among the most significant characteristics of thriller there are fast-paced action and growing tension $(2016: 138,162)$. The main character of a thriller is usually some kind of an agent or highly qualified specialist, in Finnish thrillers however it is still quite often a police officer (2016:138). As Paula Arvas and Voitto Ruohonen characterize it, the threat that main characters fight against usually comes from different kind of secret societies, international organizations, as well as it may be imposed by corruption and serial killers (2016:139). The events, as impossible as they may seem, shall be described in a way that makes the reader believe in them (2016:137). ${ }^{1}$

The genre has been gaining popularity among many crime fiction authors in Finland. However, there are two names that can never be omitted as Finnish crime literature, especially thriller, is the discussed subject. Ilkka Remes and Taavi Soininvaara belong to the most significant and, accordingly, most often read thriller writers in Finland. The aim of the article is to describe briefly the main features of the works of both authors and to concentrate first and foremost on those topics mentioned by them that are considered to be less typical for this subgenre of criminal fiction. Examples provided by the novels suggest that both Remes and Soininvaara, apart from discussing the biggest global threats, try to draw the readers' attention also to the problems that an individual may face and to the changes concerning interpersonal relationships affecting the society and its traditional values.

\section{GENERAL CHARACTERISTICS OF ILKKA REMES' AND TAAVI SOININVAARA'S NOVELS}

\subsection{ILKKA REMES}

Ilkka Remes (born 1962) can be considered the most productive author among the Finnish thriller writers. The author appears in public extremely rarely, there are not many up-to-date interviews available revealing any details concerning his private life or the attitude to his literary work (see also: Ingström 2006). The scarce quantity of theoretical material available forces anyone trying to analyze his novels more thoroughly to consider using less academic sources, such as for example news services or bookstores' official webpages. This is why the bibliography of the presented article includes

\footnotetext{
${ }^{1}$ For a more detailed description and historical development of the genre with its different subgenres refer to Scaggs (2005:105-121), Arvas \& Ruohonen (2016:135-189).
} 
among the others some internet sources that provide data, which cannot be found in other types of publications.

Not only does Remes belong to the most popular thriller writers, but to the most popular writers in Finland in general. In 2006, for instance, one of his novels occurred to be the most often bought novel in Finland according to the official statistics. Another one was among the bestsellers a year before (YLE1). It is a considerable success as the popularity of criminal fiction in Finland implies that many titles representing the genre are published every year. Remes' novels are also appreciated by the critics and scholars (see for example: Ingström 2006). He is also an author of several thrillers dedicated to a younger readership (Arvas \& Ruohonen 2016:160).

Ilkka Remes has so far published more than 20 novels, of which the latest is Vapauden risti (2017; English meaning of the title: The Cross of Freedom M.K.) from 2017 (IR). However, his works are rarely translated to other languages. Several novels have only been translated to German. This is why his works have so far been unavailable for a wider audience. He is appreciated by the critics mostly for being a professional background researcher (Varis 2007:33). To put it simply, he is extremely well-prepared to make his readers aware of the problems the global society has to be ready to face.

Remes' novels cover a wide range of subjects, among which the most significant one appears to be terrorism, its different forms (such as for example eco-terrorism) and purposes as well as international co-operation in the fight against it. Moreover, his works deal with the problem of nuclear threat, development of biological and chemical weapons, advanced science, modern technologies and their improper use, the importance of inventions and discoveries (about the subjects discussed by Remes see also: Ingström 2006, Arvas \& Ruohonen 2016:158-160). Remes does not hesitate to describe such appalling problems present in today's world as religious fanaticism, combining religious issues with current political situation of a given country, the controversies arising within a religious system as new scientific facts are revealed. It is nothing unusual for the author to skillfully combine many of these subjects with one another within one novel only.

One of the author's most alarming messages to the Finnish readers in particular seems to be that Finland shall no longer be viewed as one of the safest places in the world, not even in Europe. The problems that the Finnish society experiences and the threats it has to face are getting more and more similar to those present in all modern highly developed countries.

What could possibly be seen as a kind of consolation is that it is all merely a warning. The readers shall bear in mind that terrorist attacks portrayed in Remes' novels are only a product of his literary imagination. On the other hand there are some opinions emphasizing that Remes seems extremely reliable in what he is describing. According to Mikko Varis, one of the greatest 
challenges for the authors of thrillers (from Finland in this particular case) is to transpose some global problems to the Finnish reality (Varis 2007:33). Providing the example of the attack on the presidential palace that happens in one of the Remes' novels and regarding it a spectacular idea, Varis suggests that the writer deals with that challenge well. It is namely questionable if such an incident could have undoubtedly been prevented if the threat was real (2007:33).

\section{2. TAAVI SOININVAARA}

Taavi Soininvaara (born 1966) together with Ilkka Remes is the most popular and appreciated modern thriller writer in Finland at the moment. Similarly to Remes in his works he has combined the subjects concerning threats caused by the changes happening globally with issues important particularly from the Finnish point of view. In addition to that, the author does not forget about the problems that an individual may face in today's world full of emotional traps.

Taavi Soininvaara is an author of almost twenty novels, most of which have been translated to German. What might be perceived as a rare exception, in addition to that the novel Ebola-Helsinki, was translated to Polish in 2010 under the title Wirus Ebola w Helsinkach (cf. Soininvaara 2010b; English meaning of the title: Ebola virus in Helsinki - M.K.). In 2003 Taavi Soininvaara was awarded Vuoden Johtolanka-prize for the best crime novel in Finland (TS). Although the author seems to appear in public relatively more often, the materials concerning his works are rather scarce, as in the case of Ilkka Remes.

What has previously been said about Ilkka Remes concerning his thorough background research, applies to Taavi Soininvaara as well (Varis 2007:33).

Main characters appearing in Soininvaara's thrillers have to deal with a wide range of problems that constitute the most serious threats to the human civilization and peace nowadays. Among the subjects the author is most interested in the reader can find first and foremost the endless international conflict and struggle to control the whole world by possession of nuclear weapon, human trafficking, or, in other words, all possible modern ways of slavery. Moreover, among the topics often mentioned in the novels there appear drug trafficking, international terrorism and surveillance, the role of scientific development and modern technologies in maintaining peace and stability, but also scientific development in some specific areas (such as manufacturing of weapons, especially development of biological and nuclear weapon) as a threat to the mankind. In his earlier novels (as for example in Koston Komissio, 2005; English meaning of the title: The Revenge Commission - M. K.) Soininvaara discusses also the issues connected with the 
widening of the European Union, what delivers some interesting research material for those interested in the Finnish (and not only) society's different attitudes towards the union membership. Moreover, Koston Komissio gives an insight into the structures of the European Union and functioning of some European organizations responsible for safety and terrorism prevention.

In addition to that, in some novels Soininvaara emphasizes the problem of corruption among the police (Arvas \& Ruohonen 2016:269). The characters and situations presented may give the readers an impression that in the world described by the author it is extremely difficult to find an ally in the fight against different faces of evil, or, to put it simply, someone to trust on in the gradually collapsing society. That is why there is nothing unusual in the fact that at times it may seem to the reader that Soinivaara's characters are involved in their private crusade against literally the whole world. Taking into consideration the above mentioned facts and what has already been said about Ilkka Remes' portrayal of Finland it can be stated that Soininvaara's vision is similar to that of Remes. Finland portrayed in his novels is no longer as safe place as we are eager to believe in.

\section{USUAL PROBLEMS OF UNUSUAL PROTAGONISTS}

As it has already been stated, the thrillers written by the most popular Finnish thriller authors undoubtedly include most of the elements considered as characteristic features of international and political thrillers. Their main characters save the world, or at least some part of it from nuclear or natural disasters, fight against well-organized international crime and corruption, sometimes alone or only with a small group of supporters. They reveal the truth concerning some facts that prevent catastrophes, or on the contrary, try to hide certain secrets as deep as possible. They are highly skilled, one-of-a-kind specialists, scientist and agents.

However, the everyday problems they have to solve do not differ from what an average member of the society has to face. On the contrary, these problems seem to affect them to a considerable extent. Although they are usually successful in their jobs, family life does not always precede in the same successful way. Their relationships collapse, some of them suffer even from serious childhood traumas. The heroes pay a considerable price for their professional success.

\section{1. DOWN-TO-EARTH HEROES WITH AVERAGE PROBLEMS}

According to some critics, Remes' characters are not considered particularly interesting (Ingström 2006). As different as the opinions might be on that matter, it is clear that by creating his characters and their complicated 
stories the author tries to convey an important message to his readers. This is why these literary heroes, especially some aspects of their private lives, are worth investigating.

One of Remes' novels protagonists, Antti Korpi, seems to be an example of a superhero in the Finnish literary world. In one of the novels he manages to save Europe, maybe even the whole world, from nuclear disaster. In another one, he takes part in an extremely dangerous mission trying to safe life of a Finnish woman kidnapped in Iraq. In severe conditions, in which he works there is no place for any trace of weakness, no place for personal feelings nor second thoughts concerning in what he is involved. However, the greatest challenge Korpi has to face in his life comes from a completely different direction.

Antti Korpi has in fact been a policeman, but is currently working for an anti-terrorist organization within the structures of the European Union. His life seems therefore to be divided between Finland and Brussels. Due to changeable living conditions caused by his work, unstable lifestyle and high risk involved in his job Korpi experiences serious difficulties in relationship with his family members. Korpi is married and has a son, which means that he is responsible not only for his own safety. It is a challenge that cannot always be fulfilled. As a result of his actions taken in order to solve one of the mysteries he faces, Antti puts at risk his son's life. It should also be mentioned that due to both Antti's and his wife's busy professional life they are forced to hire a baby sitter to look after Aaro. They simply do not have enough time to spend with their son nor can always make sure the boy has everything he needs. What makes the family's situation even more complicated, Soile, Antti's wife, seems to be unsure of her feelings towards her husband. Their marriage is on the verge of a serious crisis.

Another Antti in Ilkka Remes' literary world, Antti Kaira, experiences very similar problems to those already mentioned. He is a scientist, concentrated on his job and devoted to it. Although he is experiencing temporary problems at work, taking into consideration his skills and expertise the future seems rather bright. However, when his fiancée's life becomes endangered, and what is worse, she is claimed to have participated in a terrorist attack, he risks his own life in order to save her and to solve the great mystery involved. Despite realizing that he is taking part in something which might have huge significance to the whole world, the only thing that really matters to him is the life of his future wife. Another fact that contributes to the superhero's human face is that he suffers because of some traumatic memories concerning the death of his friend, Eero. Kaira feels guilty because in his opinion he should have been able to rescue him. He cannot overcome it and every time when the memories emerge, it is a situation that can be compared to a panic attack. Kaira is a scientist, a reasonable person and he probably realizes that nothing 
more could have been done to save Eero. His attitude to the memory of a friend, as well as to his fiancée Tina, proves that even when the everyday concerns are a mixture of advanced science, international conspiracy, fear and fight for one's own life, there is still space for true feelings towards other people.

Joanna Vahtera is probably the most significant female character in Remes' novels. She is a professional police officer, and, what is more, unique in Finland due to her education in the area of criminal profiling. She is involved in many cases demanding special forces to solve the mystery and could therefore feel absolutely satisfied with how her life looks like: with her job, social position, respect she has gained in the professional environment. However, there is a serious disadvantage of her lifestyle full of professional challenges. In one of the novels titled Nimessä ja veressä (2005; English meaning of the title: In the name and the blood - Ingström 2006), the reader focuses on Vahtera's problems with building a relationship for life, resulting in her longing for a stable family life. The problem surfaces as Vahtera participates in an investigation in a small community, where big families with more that one child are nothing unusual.

Not only positive characters in Remes' novels have to fight with their personal nightmares. There are also some villains whose deeds are determined by theirs personal traumas, traumatic childhood memories and an inner need to take revenge on certain people. Tuija Karam, one of the characters from the novel Nimessä ja veressä, occurs to be responsible for most of the dreadful events described in it. The background for her sadistic inclinations shall be sought in her childhood memories. Although she participates in the preparation of a terrorist attack helping a person who is involved in the procedures for some ideological reasons, her own ideology could not be much different. Actually there is no ideology at all as her only aim is to take revenge on people responsible for her unhappy childhood and school years, among the others schoolmates and teachers who used to mistreat her. Moreover, the emotional disorder she suffers from is to a great extent caused also by a tragedy that happened in her family when she was a young girl. Namely, her father murdered their family, trying to murder her as well. Tuija managed to escape and survived, since her father committed a suicide right after she had run away. Through the whole life she was hiding the truth and according to the official version of the story her family died in a car accident. However, traumatic memories could not have been completely removed from her mind and when they surface, the consequences are terrifying.

It may be assumed that by introducing the story of Tuija and her traumatic background the author is trying to emphasize first of foremost the importance of balanced childhood, the role of factors such as for example parental care and sense of security in the process of growing up. Tuija had no chance for 
such balance when she was a child and the improper environment in which she was growing up led to her emotional disorder.

\section{2. COMPLICATED CHARACTERS, SIMPLE PROBLEMS}

Analyzing the inhabitants of the literary world created by Taavi Soininvaara, one may encounter similar problems that main protagonists of the novels have to face. Similarly to the Remes' great heroes, they are highly qualified professionals prepared to work in extremely dangerous conditions. However, the most challenging problems they have to solve are provided to them by their everyday life, personal and family issues, and in some cases their past and the shadows it casts over them. In one of Soininvaara's novels with Finnish title Pakonopeus (2010a; English meaning of the title: Escape velocity - M.K.) we meet two characters, whose cases are the best examples representing the author's approach to these issues.

Leo Kara is an agent working for an organization responsible for safety and stability first and foremost of the European Union, but taking into consideration the importance of the issues they deal with, there is in fact the whole world in question. In several cases during his career Leo has been in a situation when his life was endangered. He is extremely resistant, used to severe conditions and danger. However, there is something about his past that affects every aspect of his life and there seems to be no way escape from it. Kara experienced a huge trauma in his childhood, when he lost his family in mysterious circumstances. He cannot remember the details of what exactly happened that time and this means an endless nightmare for him. He would like to know the truth about his family's past which proves, that although he may seem a tough or even cold person, family plays an important role in his life. What makes private issues even more complicated for Kara is that he finds it difficult to establish a relationship. His emotional life seems to be pretty unstable. Although he has a girlfriend in Vienna, where he works and lives permanently, it does not prevent him from getting involved in a romance while he is in Helsinki in order to solve an intricate case he is working on.

Kati Soisalo, a lawyer from Helsinki and a friend of Leo Kara, might be seen as an example of a modern, successful woman, combining professional career with childcare. It is, however, only the first impression the reader may get. Soisalo is indeed a mother of a wonderful girl, but her marriage occurred to be a nightmare. As a result she is forced to divorce from her violent husband. This is only the beginning of her problems as during holidays in Croatia her daughter Vilma is kidnapped.

Determined Soisalo gets engaged in a fight against powerful criminal organizations, trying to fight off an international human trafficking mafia. However, first and foremost she wants to get her daughter back. She understands 
the importance of the steps she undertakes together with her faithful friends. She knows the risks and bears in mind that the chances of failure are far too high. In spite of that she decides to continue the desperate fight in order to save her daughter's life. Although being able to help other families in a similar situation is undoubtedly a factor making the risk worth undertaking, Vilma's safety is her mother's first priority. As cruel as it might seem, helping others is only a kind of a positive side effect for the desperate mother trying to find her missing daughter. Moreover, Kati's efforts acquire even more features of a private war when she realizes that her ex-husband is involved in some criminal procedures. Soisalo's determination proves that there is nothing more important in her life that the safety of the person she loves most, even if she risks losing everything else she has to guarantee it.

Last but not least, another significant protagonist from Soininvaara's novels, Arto Ratamo, working for the Finnish Security Intelligence Service, at his work faces some problems that demand high stress resistance and emotional stability. A reader could expect him to be a tough superhero, who not only avoids getting involved in any kind of relationships, but first and foremost, he simply has no time for that. As surprising as it may occur, after his wife's death Ratamo is taking care of his daughter, Nelli (see also: Arvas \& Ruohonen 2016:160). Although he is often forced to ask the girl's grandmother for help, he only does it to make sure the girl gets the care she needs, not to escape from the responsibility. Even while he is working with his team on the cases of dreadful political murders (constituting the main plot of the novel Koston Komissio) that have shocked the whole Europe, he finds time for his daughter and, for example, attends her violin concert. Moreover, even despite being used to extremely stressful situations at work, Arto is feeling slightly ill at ease when they are facing contemporary relationship problems with his girlfriend. As tough as Arto Ratamo may seem in his professional environment, he definitely is an example of a person who knows what really counts in life and is ready to fight, both literally and metaphorically, in order to protect the people closest to him.

Emphasizing the role of proper relations among its members within a family and the importance of a family as a basis for the balanced society Remes and Soininvaara follow the direction that also other great masters of the Finnish crime literature such as Matti Yrjänä Joensuu and Leena Lehtolainen follow. In other words, although thrillers representing different subgenres can be considered a new wave of Finnish crime fiction, their authors at the same time make their novels correspond with the classics of the genre. The social focus of the novels by writers such as for example Joensuu has frequently been emphasized by those who analyze them (see for example Ruohonen 2005, 2008, Kokotkiewicz 2014). Introducing some alarming social problems, as well as the problems of the individuals, Remes and Soininvaara, like other 
crime fiction authors, use their genre as a mean to explore the problems which their societies face. Although the issues in question may at first seem of lesser importance for the main plot of many international, political and eco-thrillers, the authors' message hidden in them is clear: the problems of an individual cannot be ignored as in the long run they might affect badly the stability of the whole society.

\section{SUMMARY AND CONCLUSIONS}

All in all, it can be stated that so far the greatest masters of the modern Finnish thriller have been following the scheme applying more generally to the authors of crime fiction in Finland and other Scandinavian countries. The main factor influencing their success is definitely connected with the subjects they discuss in their novels and with the way they do it. It is the authors' ability to react to global changes and depict the societies they represent that the readers most appreciate. Ilkka Remes and Taavi Soininvaara have proved that it is possible to combine literary fiction with the description of real societies and the difficulties that challenge them. They have been using their genre as a tool to deal with serious issues, threatening both individuals and smaller communities and, on a larger scale, the whole humankind.

What the authors want to emphasize by building the plot of their novels around some characters with complicated background is that stability in private life, interpersonal relationships, family relations, especially balanced childhood are the factors that influence an individual to the greatest extent. Any serious aberrations concerning them can constitute a threat to the whole society. It is a kind of a threat that is imposed by the society itself and no other kind of enemy coming from outside can be blamed for it.

Moreover, providing the readers with some convincing examples of the problems belonging to different categories, both global and those applying rather to smaller societies, the authors have shown that thriller shall not anymore be treated as a literary genre with first and foremost entertaining function. It has to be emphasized that also in this respect their attitude resembles the works of classical, more traditional, so to say, authors of criminal fiction.

It is claimed that Remes and Soininvaara have opened the way for their future followers in Finland (Arvas \& Ruohonen 2016:160). As new authors specialized in political, international and eco-thrillers appear on the Finnish literary scene, the readers shall expect the further evolution of the genre and further evaluation of the subjects discussed within it. 


\section{REFERENCES}

Arvas, P., Ruohonen, V. (2016). Alussa oli murha. Johtolankoja rikoskirjallisuuteen. Helsinki: Gaudeamus.

Ingström, P. (2006). Food for thought. Books from Finland 1/2006, p. 35-38. Retrieved from http://www.finlit.fi/booksfromfinland/bff/106/ingstrom.htm (Jan 18, 2014).

IR = Ilkka Remes's official webpage. Retrieved from https://ilkkaremes.wordpress.com/ (Jan 3, 2018).

Kokotkiewicz M. (2014). Immigrants in Finland as a problem discussed in Leena Lehtolainen's Minne tytöt kadonneet. Folia Scandinavica 16, p. 66-76. Retrieved from: https://repozytorium.amu.edu.pl/jspui/bitstream/10593/12700/1/10252-vol16- 05_Kokotkiewicz.pdf $\left(31^{\text {st }}\right.$ Aug 2018)

Ruohonen, V. (2005). Paha meidän kanssamme. Matti Yrjänä Joensuun romaanien yhteiskuntakuvasta. Helsinki: Otava.

Ruohonen, V. (2008). Kadun varjoisalla puolella. Rikoskirjallisuuden ja yhteiskuntatutkimuksen dialogeja. Helsinki: SKS.

Scaggs, J. (2005). Crime Fiction. London, New York: Routledge.

$\mathrm{TS}=$ Taavi Soininvaara's official profile. Retrieved from https://otava.fi/kirjailijat/taavisoininvaara/\#.WnhUxLiEVFs (Feb 5, 2018).

Varis, M. (2007). Suomalaiset dekkarit, nyt. Parnasso 4/2007.

YLE1 = Ilkka Remeksen terrorismiromaani oli viime vuoden suosikkikirja 2007. 01. 30. Retrieved from https://yle.fi/uutiset/3-5759848 (Jan 4, 2018).

\section{WORKS OF FICTION:}

Remes, I. (2005). Nimessä ja veressä. Helsinki: WSOY.

Remes, I. (2017). Vapauden risti. Helsinki: WSOY.

Soininvaara, T. (2002). Koston Komissio. Helsinki: Tammi.

Soininvaara, T. (2010a). Pakonopeus. Helsinki: Otava.

Soininvaara, T. (2010b). Wirus Ebola w Helsinkach. Translation: Bożena Kojro. Rusiec: Wydawnictwo Kojro.

\section{Martyna Kokotkiewicz}

Uniwersytet im. Adama Mickiewicza w Poznaniu

Wydział Neofilologii

Zakład Ugrofinistyki

al. Niepodległości 4

61-874 Poznań

Poland

martynak@amu.edu.pl 